\title{
РОЛЬ МЕДИЧНОЇ СЕСТРИ В ПРОВЕДЕННІ СПИННОМОЗКОВОЇ ПУНКЦІЇ ПРИ ЧЕРЕПНО-МОЗКОВІЙ ТРАВМІ
}

\author{
Б. В. Дорошенко ${ }^{1}$, Я. М. Кіцак², Р. М. Ляхович², М. Я. Джус ${ }^{3}$ \\ ${ }_{1}^{1}$ Івано-Франківська обласна клінічна лікарня \\ ${ }^{2}$ ДВНЗ «Тернопільський державний медичний університет \\ імені І. Я. Горбачевського МОЗ Украӥни» \\ ННI медсестринства

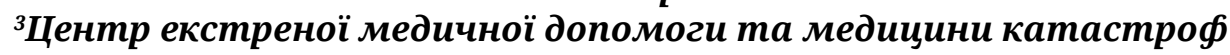 \\ Тернопільської обласної ради
}

У статті висвітлено основні принципи проведення спинномозкової пункції хворим із черепномозковою травмою, а також їі вирішальне значення при встановленні діагнозу. Значну увагу приділено показанням та протипоказанням до виконання спинномозкової пункції, а також підготовці хворих до цієї процедури.

\section{THE ROLE OF A NURSE IN THE SPINAL PUNCTURE WHEN CRANIOCEREBRAL TRAUMA}

\author{
B. V. Doroshenko', Y. M. Kitsak ${ }^{2}$, R. M. Liakhovych ${ }^{2}$, M. Y. Dzhus ${ }^{3}$ \\ ${ }^{1}$ Ivano-Frankivsk Regional Clinical Hospital \\ ${ }^{2}$ I. Horbachevsky Ternopil State Medical University \\ Institute of Nursing \\ ${ }^{3}$ Center of Emergency Care and Disaster Medicine of the Ternopil Regional Council
}

\begin{abstract}
The article outlines the basic principles of spinal puncture in patients with craniocerebral trauma, as well as its crucial role in the diagnosis. Considerable attention is paid to indications and contraindications for performing spinal puncture, as well as the preparation of patients for this procedure.
\end{abstract}

Вступ. Серед широкого арсеналу діагностичних досліджень, які проводять в нейрохірургічному відділенні, важливе місце займає спинномозкова пункція (люмбальна пункція, поясничний прокол), яку проводять з діагностичною або лікувальною метою [1]. Поява цього методу сягає кінця XIX ст. проте не втрачає актуальності й сьогодні. Основним і найпоширенішим залишається метод люмбальної пункції (лП) Ouincke, незважаючи на існування різних методів отримання ліквору. Спочатку метод люмбальної пункції був використаний Ouincke у хворих із туберкульозним менінгітом та гідроцефалією з лікувальною метою, і лише згодом дослідження спинномозкової рідини почали використовувати для діагностики й уточнення клінічної картини захворювання [5].

Спинномозкову рідину використовують для проведення діагностичних досліджень (загальний аналіз рідини, визначення рівня цукру, хлоридів, кліткових (с) Б. В. Дорошенко, Я. М. Кіцак, Р. М. Ляхович, М. Я. Джус, 2018 елементів та білка). Аналіз спинномозкової рідини дає немало інформації для встановлення діагнозу захворювання та визначення тактики лікування. Також спинномозкову пункцію в деяких випадках використовують з лікувальною метою - виведення ліквору для зниження внутрішньочерепного тиску, введення медикаментів та санація субарахноїдального простору [3].

Основна частина. У структурі травматизму, ушкодження головного мозку складають до 30 \% та є однією з провідних причин інвалідизації населення.

Черепно-мозкова травма, що виникає внаслідок травматичного ушкодження тканин голови, головного мозку, а також його судин та оболонок, часто супроводжується стисненням головного мозку та внутрішньочерепним крововиливом і вимагає негайної медичної допомоги. Лікування постраждалих проводять в нейрохірургічному відділенні [1]. 
Медична сестра попереджує хворого про проведення цієї маніпуляції. Вона бере участь у психологічній підготовці хворого, інформує про необхідність процедури, безпеку проведення та діагностичну доцільність. Спинномозкову пункцію проводять в чистій перев'язочній на столі або каталці в лежачому положенні хворого на боці. Якщо він збуджений, із відома лікаря вводять заспокійливі засоби. Хворого необхідно роздягнути, він повинен лежати на боці з приведеними до живота ногами та зігнутою головою до грудної клітки.

Медична сестра допомагає хворому зайняти відповідне положення, одночасно накриває маленький столик, на якому розміщується стерильне полотенце чи пелюшка, марлеві шарики, шприц для проведення анестезії об'ємом 2 мл, розчин лідокаїну або новокаїну, пробірки для забору ліквору, голки для спинномозкової пункції з мандреном, розчин спирту, спиртовий розчин йоду або Люголя, бетадину, манометр для вимірювання лікворного тиску (скляна канюля). якщо хворий в безсвідомому стані, медична сестра шляхом підведення своїх рук під потилицю та коліна хворого зближує їх, що призводить до вигинання поперекового відділу хребта [6].

Нейрохірург одягає стерильні рукавички, обробляє руки, шкіру в поперековій ділянці спиртовим розчином йоду або Люголя, бетадином (2 рази), після чого обробляє спиртом. Лікар проводить місцеву анестезію в ділянці L4-L5, тобто в зоні люмбального проколу.

Прокол проводять в сагітальному напрямку за допомогою спеціальної пункційної голки. Довжина

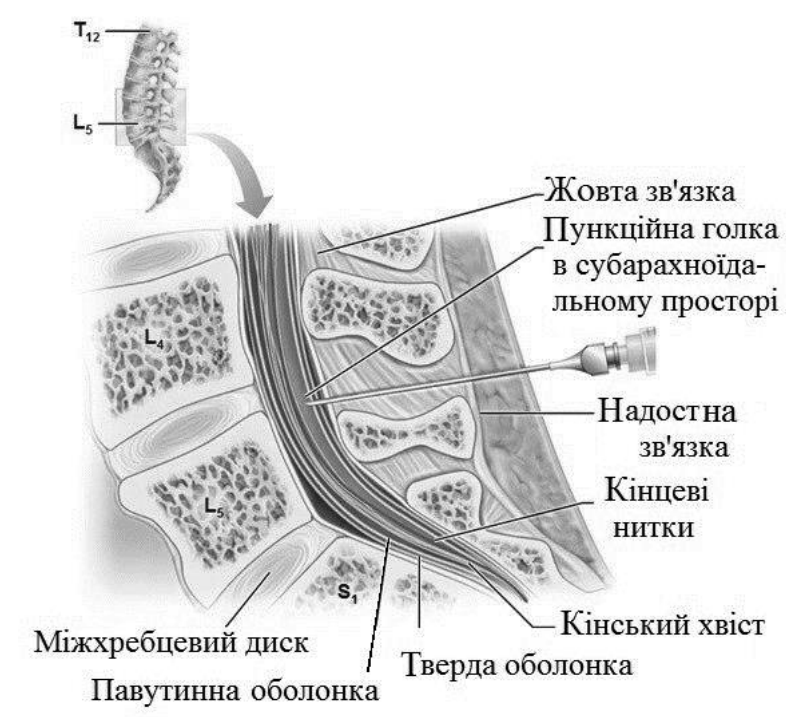

Рuc. 1. Положення пункційної голки під час проведення люмбального проколу (www.mainlinehealth.org). голки 10-12 см, товщина 0,5-1 мм. Верх її зрізаний під кутом $45^{\circ}$ (рис. 1). Під час проколу твердої мозкової оболонки виникає відчуття «провалювання», після чого ліквор починає витікати краплями [7].

Після проведення люмбального проколу повільно видаляють мандрен. При наявності ліквору під'єднюють манометр (скляна канюля з перехідником) по висоті рівня ліквору в манометрі визначають лікворний тиск.

у нормі лікворний тиск становить 100$200 \mathrm{MM} \mathrm{вод.} \mathrm{cm}$.

Для дослідження лікар бере 2-4 мл рідини 3-під мандрена, яку негайно відправляють до лабораторії. За необхідності проводять ліквородинамічні проби (Квекенштедта та Стукея). Після ЛП необхідно уникати вібрацій і значних змін температури, тому що це може змінити результати аналізу. Пробірки з ліквором необхідно пронумерувати і щільно закрити.

Техніка виконання:

Після визначення лікворного тиску проводять стиснення пальцями рук яремних вен на шиї хворого протягом 5-6 с. При цьому відбувається підвищення лікворного тиску приблизно в 3 рази стосовно попереднього показника. При пробі Стукея проводять стиснення (кулаком руки) великих вен живота в ділянці пупка. При цьому лікворний тиск підвищується у 2 рази стосовно попереднього показника. При зупиненні стиснення вен при пробах Квекенштедта та Стукея тиск спинномозкової рідини швидко повертається до попереднього показника. Ліквородинамічні проби допомагають встановити прохідність в лікворовмістимих просторах.

Труднощі можуть виникати при спондильозі, хворобі Бехтерева, попаданні в епідуральні судинні сплетіння та ін. Кількість вилученого ліквору залежить від мети пункції та стану хворого [4].

Після проведення спинномозкової пункції місце проколу обробляють спиртовим розчином йоду або Люголя, закривають лейкопластиром. Хворого на каталці доставляють в палату. Хворий повинен перебувати в лежачому положенні 24 год, з яких 2-3 год без подушки на боці з піднятими нижніми кінцівками. Спостереження за хворим у динаміці.

Особливої уваги потребує питання про наявність небезпеки при проведенні ЛП. Вона виникає при тяжких масивних крововиливах у мозок та ішемічних вогнищах із швидким розвитком перифокального набряку, який поширюється навіть на неуражені зони мозку з одночасним погіршенням ліквороциркуляції 
і венозного відтоку, збільшуючи тиск у черепі. У цьому разі створюються умови, за яких навіть незначні втручання у вигляді ЛП часто провокують дислокацію мозкових структур із розвитком синдромів «верхнього» і «нижнього» вклинення. Клінічним критерієм у таких випадкахє швидкий розвиток мозкової коми [4].

Для проведення люмбальної пункції існують абсолютні та відносні показання. До абсолютних протипоказань відносять об'ємний процес задньої черепної ямки або скроневої частки мозку. Відносними протипоказаннями до проведення люмбальної пункції $\epsilon$ кома, шок, колапс, пролежні та гноячкові ураження шкіри в поперековій ділянці [2].

При патологічних станах, що пов'язані з небезпекою ускладнень внаслідок люмбальної пункції, доцільно від неї утримуватися і використовувати

\section{СПИСОК ЛІТЕРАТУРИ}

1. Ринденко В. Г. Люмбальна пункція в діагностиці черепно-мозкової травми : методичні рекомендації / В. Г. Ринденко, М. І. Завеля, О. Л. Чернов. - Харків : «Оберіг». - 2008. - 24 c.

2. Захарія К. А. Попередження помилок при дослідженні спинномозкової рідини / К. А. Захарія, Н. П. Педько, Б. В. Западнюк // Лабораторна діагностика. - 2011. № 4. - C. 35-43.

3. Захарія К. А. Шляхи підвищення якості лабораторних досліджень : посібник для лікарів та середнього медперсоналу / К. А. Захарія, Н. П. Педько ; за ред. К. А. Захарія. - К., 2005. - 37 с. так звані «альтернативні» методи обстеження, що дозволяють уникнути дислокації та защемлення стовбура: ехоенцефалоскопія, ангіографія, КТ, МРТ. якщо результати перелічених альтернативних лп методів досліджень виявляються недостатніми для встановлення діагнозу, може все-таки виникнути питання про дану маніпуляцію. При цьому необхідно ретельно зважити і зіставити пов'язаний із нею ризик й можливу діагностичну результативність.

Висновки. Виконання спинномозкової пункції при діагностиці черепно-мозкової травми необхідно проводити у строгій послідовності, після виключення внутрішньочерепних об'ємних процесів. Виконання пункції дозволяє підтвердити або виключити внутрішньочерепну кровотечу при відсутності КТ або при ії негативних результатах.

4. Малахов В. О. Основи клінічної лікворології : навч. посіб. / В. О. Малахов, О. О. Потапов, В. С. Личко. - Суми : Сумський державний університет, 2016. - 356 с.

5. Gil Shlamovitz Z. Lumbar Puncture Updated : Medscape. Clinical Procedures Articles / Gil Shlamovitz Z., Nirav R. Shah // Brain and Spinal Cord. - 2015.

6. Plebani M. Errors in clinical laboratories of errors in laboratory medicine / M. Plebani // Clin. Chem. Lab. Med. 2006. - Vol. 44 (6). - P. 750-759.

7. Sechusen D. A. Study of cerebrospinale liquor / D. A. Sechusen, M. M. Recves, D. A. Fomin // Medicine. - 2006. Vol. 21, No. 4. - P. 197-202. 